\title{
Urinary Incontinence Amongst Malaysian Women in Selangor: Prevalence, Types and Risk Factors
}

\author{
Hardip Kaur Dhillon, * , Quek Kia Fatt ${ }^{1}$, Harbindar Jeet Singh ${ }^{2,3}$, Gurpreet Kaur ${ }^{4}$, \\ Anuar Zaini Md Zain ${ }^{1}$, Rusli Bin Nordin ${ }^{5}$ \\ ${ }^{1}$ Jeffrey Cheah School of Medicine \& Health Sciences, Monash University Malaysia, Bandar Sunway, Malaysia \\ ${ }^{2}$ Faculty of Medicine, Universiti Teknologi MARA, Sungai Buloh Campus, Sungai Buloh, Selangor, Malaysia \\ ${ }^{3}$ I-PerFORM, Universiti Teknologi MARA, Sungai Buloh Campus, Sungai Buloh, Selangor, Malaysia \\ ${ }^{4}$ Selangor State Health Department, Wisma Sunway, Shah Alam, Selangor, Malaysia \\ ${ }^{5}$ Faculty of Health and Medical Sciences, Taylor University, Lakeside Campus, Subang Jaya, Selangor, Malaysia

\section{Email address:} \\ hardip.kaur@monash.edu (H. K. Dhillon),quek.kia.fatt@monash.edu (Q. K. Fatt),hjsingh@salam.uitm.edu.my (H. J. Singh), \\ drpreet@yahoo.com (G. Kaur), anuar.zaini@monash.edu (A. Z. Md Zain), Rusli.Nordin@taylors.edu.my (R. B. Nordin) \\ ${ }^{*}$ Corresponding author
}

\section{To cite this article:}

Hardip Kaur Dhillon, Quek Kia Fatt, Harbindar Jeet Singh, Gurpreet Kaur, Anuar Zaini Md Zain, Rusli Bin Nordin. Urinary Incontinence Amongst Malaysian Women in Selangor: Prevalence, Types and Risk Factors. World Journal of Public Health.

Vol. 4, No. 1, 2019, pp. 10-19. doi: 10.11648/j.wjph.20190401.12

Received: February 21, 2019; Accepted: March 26, 2019; Published: April 18, 2019

\begin{abstract}
Information on urinary incontinence (UI) amongst Malaysian women remains incomplete and inconclusive. Of the few available studies, none had used the holistic approach to study UI amongst Malaysian women and information on the prevalence and the types of UI experienced by the Malaysian women therefore remains debatable. The objectives of this study were to estimate the prevalence of UI and its types in Malaysian females, determine the demographic characteristics of those with UI and to elucidate the association between potential risk factors and female UI. A validated, standardised Malay Monash Women Health Questionnaire (MMWHQ) was administered to 350 community dwelling, Malaysian women. The response rate was $86 \%(n=301)$. The dropout rate for interviews was $30 \%$. Descriptive statistics and multinomial regression were applied. The estimated prevalence of UI $(n=52)$ was $17.3 \pm 4.65 \%$ (95\% Confidence Interval $16.95-26.25 \%)$. Majority of respondents had reported no UI $(82.7 \% ; n=249)$, while $8.0 \%$ of the respondents complained of stress urinary incontinence (SUI), 5\% reported urge urinary incontinence (UUI) and $4.3 \%$ had mixed urinary incontinence (MUI). Most women with UI were of middle age, of Chinese ethnicity, with secondary education, with an income of $<$ RM999/- per month, married, had undergone vaginal childbirth with or without episiotomy and had 1 to more than 4 children. There was a significant association between UI and risk factors including menopause, increased BMI, straining hard during defecation, coffee consumption and depression in the risk factor model. The Malay version QUID was found to be a user-friendly diagnostic tool to identify types of UI. The prevalence of SUI was higher than previously reported. The association between risk factors and UI observed in this study was somewhat similar to those previously reported in a number of studies in other populations.
\end{abstract}

Keywords: Malaysian Female UI, Malay - Version Questionnaire Urinary Incontinence Diagnosis (QUID), Malay Monash Women Health Questionnaire (MMWHQ), Prevalence, UI Types, Risk Factors Model

\section{Introduction}

Urinary incontinence (UI) is not well reported in Malaysian women. Reports of its prevalence have varied from 9.9 to $44.1 \%$ [1]. This might be due to the numerous different questionnaire designs used in the documentation of the prevalence and risk factors associated with UI in Malaysian women [1]. Generally, none of the studies had used a holistic approach to the study of this problem in women. Instead of focusing the study on just the disease process of urinary incontinence (sign and symptoms), the holistic approach applied in this study had also considered 
the respondents as a whole. The questionnaire not only assessed the bodily function of female urinary incontinence and types using QUID but also attempted to identify both the environmental factors (demographic characteristics) and her lifestyle behaviour. To identify the risk factors associated with Malaysian women, the menopause specific Quality of Life questionnaire (MENQoL), pelvic floor disorders inventory questionnaire (PFDI), and the impact of UI on the psychological wellbeing (PGWBI) were used. The types of UI and the risk factors associated with these have not been well reported in the Malaysian population or for that matter in many other parts of the world. UI has frequently been referred to as a "silent epidemic", but its precise prevalence and the individuals at risk have not been well documented [2] There is therefore a need for more efforts to clearly document the prevalence, types and risk factors associated with UI in Malaysian women for its better management. There is a need for a tool that is user-friendly and yet sensitive enough to capture accurately the prevalence of UI, its types and the risk factors associated with it. Following a literature review, Questionnaire UI Diagnosis (QUID) was found to use terminology based on the International Continence Society 2002 guidelines and seemed an appropriate standardised instrument for the documentation of UI [3]. QUID was considered appropriate due to its sensitive scoring criteria and being user-friendly [4]. QUID was translated into the Malay Language and after validation was found to be a reliable tool for this study [5]. The Malay version of QUID was then used in this study to document the prevalence and subtypes while the Monash Malay Women Health Questionnaire was used to document the risk factors associated with UI. We hypothesised that UI was probably under reported in some studies and over-reported in other local and international studies. We however expected the associated risk factors to be similar to those reported in studies from other populations.

\section{Methods}

\subsection{Research Tool and Sample Size}

This was an observational, cross-sectional, populationbased study using a validated, standardised Monash Malay Women Health Questionnaire (MMWHQ) and Questionnaire urinary incontinence diagnosis (QUID) [6]. A diagnosis of stress urinary incontinence (SUI) is made when the respondents score from 4 to $15 / 15$ to the first 3 questions, and a diagnosis of urge urinary incontinence (UUI) when they score from 6 to $15 / 15$ to questions 4 to 6 [5]. The diagnosis of mixed urinary incontinence (MUI) is made based on the score of $\geq 11 / 30 \quad$ [7]. Using a previously documented prevalence of $14.5 \%$ in the Malaysia population the sample size was calculated [8]. Sample size estimation for simple random sampling was based upon the formula $\left(n=Z^{2} P(1-\right.$ $\mathrm{P}) / \mathrm{d}^{2}$ ) used for prevalence study [9]. Sample size calculation $=1.96^{2} \times 0.145 \times(0.855) /(0.05)^{2}=191$ respondents. For cluster sampling $(191 \times 2) 458$ respondents were required inclusive of $20 \%$ dropout. Eventually, 301 women completed the questionnaires. Cost consideration, administrative limitations, obtaining a minimum acceptable level of precision and confidence interval were some of the reasons for choosing this mode of sampling.

\subsection{Data Collection}

MMWHQ was used because it contained a number of internationally validated questionnaires [6]. Each booklet consisted of questions with semi-structured responses. The respondents marked a cross in the box provided or where necessary, wrote an answer in the space provided. If there were any questions the respondents found sensitive and were reluctant to answer, they were not required to answer them. Throughout the interview the respondents had the right to refuse to answer any questions in the booklet. The duration to answer the questionnaire was 30 to 45 minutes. The questions were either self-administered during the visit or completed during a face to face interview whereby the questions were read out to the respondent by the researcher and the answers ticked according to the response provided by the respondents. Both methods were considered acceptable as it did not cause any variation to the data collected. Questions that were not answered were entered into the database as missing data. About $15 \%$ of the total data was missing in this study.

\subsection{Sampling Population}

Sampling was done in two stages; cluster sampling based on the enumeration blocks provided by the Department of Statistics and simple random sampling of the households from marked maps in each enumeration block. Mixed method (MM) sampling using multiple probability techniques was applied in the recruitment process. Unlike other local studies, which had taken population samples from local hospital clinics, health centres and medical and health institutions, this study was conducted among community dwelling women living/within the administrative districts of Selangor [4]. Geographically, the sampling individuals were spread out over the whole of the state. Firstly, the Malaysian women were from similar neighbourhood or location (cluster) within the administrative districts. In order to reduce the human bias in the selection of respondents, simple random sampling was applied. This was done by identifying houses on marked streets in the maps provided by the Department of Statistics. However, at times there was no participation of women from randomly identified households within the locations. In these instances, volunteers meeting the inclusion criteria were recruited using convenience sampling through the snowball technique $(10 \%)$. Since this study was gender specific, the stratified sampling was considered inappropriate The inclusive criteria consisted of healthy women aged 18 years and above, women with well controlled noncommunicable diseases such as diabetes and hypertension. The exclusion criteria consisted of pregnant women, women who had delivered within the last 2 years, women who have 
had an abortion within the year, and women who had undergone recent surgery on their reproductive tract or had undergone cancer treatment in the last six months. The decision to include or exclude volunteers from the study was done at the first contact.

\subsection{Statistical Analysis}

All quantitative analyses were conducted using statistical tests in SPSS for Windows (version 20, SPSS IBM). Descriptive representation namely, mean, mode, standard deviation, frequency and percentage was used to describe the demographic characteristics of the respondents, prevalence of urinary incontinence symptoms, specific risk factors associated with women with UI (Tables 1 and 2). Binary logistic regression was applied to investigate the relationship between the factors and UI. The reference category was set at 'Yes'. The backward stepwise method was used and the overall statistics score was $0.373, \mathrm{df} 7, \mathrm{r}=1.000$. The Omnibus Test of Model Coefficients gave an overall indication of how well the predictor variables in the model had performed in Block 1 compared to Block $0(\chi 2=35.098$, df 9, $\mathrm{p}=0.001)$. The Hosmer and Lemeshow goodness of fit Test indicated that the model was worthwhile when the significance level was greater than $0.5(\chi 2=6.493, \mathrm{df} 8, \mathrm{sig}=0.592)$. The model summary (-2Log likelihood-230.964, Cox \& Snell R square 0.110 , Nagelkerke R square 0.183 ) suggested that between 11.0 and $18.3 \%$ of the variability was explained by the variables entered into the model. Fifteen variables were entered at step 1 . These included ethnicity, percentage body fat range, percentage of total body water (TBW), BMI score, menopausal status, postmenopausal symptom of lacking energy, dissatisfaction with life and change in libido, frequency in coffee consumption, straining hard to have bowel action, incomplete emptying after bowel action, push on the vagina to complete bowel action, employment, depressive mood score and general health score. In step 6, the final step, six more variables were no longer in the equation. They consisted of the following: postmenopausal symptoms; change in libido $(\mathrm{p}=0.012)$ and dissatisfaction in life $(\mathrm{p}=0.057)$. Pelvic floor distress inventory; incomplete emptying after bowel action $(\mathrm{p}=0.075)$ and pushing on rectum or vagina to complete bowel action $(p=0.055)$. Ethnicity; Chinese $(p=0.348)$ and Malay $(p=0.261)$ and finally, body fat percentage; optimal range $(p=0.49)$ and overweight $(\mathrm{p}=0.605)$. (Table 3$)$.

\section{Results}

\subsection{Prevalence and Types of UI}

Table 1 presents the estimated prevalence and the subtypes of UI. There were more women complaining of stress UI, than urge or mixed UI. By using the QUID criteria s score criteria to define UI [3], 249 (82.7\%) women had reported no UI. Within this group, almost half the women $(n=147,48.8 \%)$ had scored zero while others $(n=102,33.9 \%)$ had scored $1 \leq$ $3 / 15$ for both SUI and $1 \leq 5 / 15$ for UUI questions. Their response to the severity ranged from "rarely" to "once in a while" and therefore this subgroup was diagnosed to have minimal urine leak (MUL) within the no UI category

Table 1. Estimated Prevalence of UI and UI Types.

\begin{tabular}{|c|c|c|c|}
\hline & \multicolumn{2}{|c|}{ Prevalence n\% } & \multirow{2}{*}{ Total } \\
\hline & No & Yes & \\
\hline QUID score criteria Urinary Incontinence [3] & $249(82.7)$ & $52(17.3)$ & $301(100)$ \\
\hline \multicolumn{4}{|l|}{ Types of UI applying QUID score criteria } \\
\hline i. Stress urinary incontinence $\mathrm{T}$ (SUI score $4 \geq / 15$ ) & $277(92.0)$ & $24(8.0)$ & $301(100)$ \\
\hline ii. Urge urinary incontinence (UUI score $6 \geq / 15$ ) & $286(95.0)$ & $15(5.0)$ & $301(100)$ \\
\hline iii. Mixed urinary incontinence (MUI score $11 \geq / 30$ & $288(95.7)$ & $13(4.3)$ & $301(100)$ \\
\hline World Health Organization question "Do you leak urine even small drops?" [10] & $134(44.5)$ & $167(55.5)$ & $301(100)$ \\
\hline
\end{tabular}

\subsection{Characteristics of Respondents}

In terms of demography the prevalence was slightly higher in the ethnic Chinese women compared to women of Malay or Indian origin (Table 2). Age (40 -64 years), education (secondary level), being married, income level < RM999/- per month, increased BMI (25.1- 30), parity, childbirth, menopausal including non-menopausal status had been associated with various UI types (SUI, UUI and MUI). Almost all characteristics had a higher prevalence of SUI than UUI and MUI (Table 2).

Table 2. Demographic characteristics of respondents and UI types.

\begin{tabular}{|c|c|c|c|c|c|c|c|}
\hline \multirow{3}{*}{ Characteristics } & \multicolumn{5}{|l|}{ Types of UI } & \multirow{3}{*}{$\begin{array}{l}\text { Pearson } \chi^{2} \\
\text { Sig (2-sided) }\end{array}$} & \multirow{3}{*}{$\begin{array}{l}\text { *Fisher Exact } \\
\text { test Sig (2-sided) }\end{array}$} \\
\hline & Total N (\%) & No UI N (\%) & SUI N (\%) & UUI N (\%) & MUI N (\%) & & \\
\hline & $301(100)$ & $249(82.7)$ & $24(8.0)$ & $15(5.6)$ & $13(4.3)$ & & \\
\hline Age, WHO criteria & \multicolumn{5}{|c|}{$6.696, \mathrm{df} 6, \mathrm{p}=0.350$} & & \multirow{4}{*}{$* 5.169, \mathrm{p}=0.482$} \\
\hline $18-39$ yr. & $64(21.3)$ & $55(85.9)$ & $6(9.4)$ & $2(3.1)$ & $1(1.6)$ & & \\
\hline $40-64 \mathrm{yr}$ & $209(69.4)$ & $169(80.9)$ & $15(7.2)$ & $13(6.2)$ & $12(5.7)$ & & \\
\hline $65-84 \mathrm{yr}$. & $28(9.3)$ & $25(89.3)$ & $3(10.7)$ & $0(0.0)$ & $0(0.0)$ & & \\
\hline Ethnicity & \multicolumn{5}{|c|}{6.881 , df $6, p=0.332$} & & \multirow{4}{*}{$* 9.294, p=0.05$} \\
\hline Malay & $106(35.2)$ & $91(85.8)$ & $10(9.4)$ & $3(2.8)$ & $2(1.9)$ & & \\
\hline Chinese & $121(40.2)$ & $95(78.5)$ & $11(9.1)$ & $7(5.8)$ & $8(6.6)$ & & \\
\hline Indian & $74(24.6)$ & $63(85.1)$ & $3(4.1)$ & $5(6.8)$ & $3(4.1)$ & & \\
\hline
\end{tabular}




\begin{tabular}{|c|c|c|c|c|c|c|c|}
\hline \multirow{3}{*}{ Characteristics } & \multicolumn{5}{|l|}{ Types of UI } & \multirow{3}{*}{$\begin{array}{l}\text { Pearson } \chi 2 \\
\text { Sig (2-sided) }\end{array}$} & \multirow{3}{*}{$\begin{array}{l}\text { *Fisher Exact } \\
\text { test Sig (2-sided) }\end{array}$} \\
\hline & Total N (\%) & No UI N (\%) & SUI N (\%) & UUI N (\%) & MUI N (\%) & & \\
\hline & $301(100)$ & $249(82.7)$ & $24(8.0)$ & $15(5.6)$ & $13(4.3)$ & & \\
\hline Education & \multicolumn{5}{|c|}{$0.950, \mathrm{df} 6, \mathrm{p}=0.987$} & & \multirow{4}{*}{$* 1.134, \mathrm{p}=0.989$} \\
\hline Tertiary/Diploma & $43(14.3)$ & $37(85.9)$ & $2(4.7)$ & $2(4.7)$ & $2(4.7)$ & & \\
\hline Secondary & $178(59.1)$ & $147(82.6)$ & $15(8.4)$ & $9(5.1)$ & $7(3.9)$ & & \\
\hline Primary /None & $80(26.6)$ & $65(81.2)$ & $7(8.7)$ & $4(5.0)$ & $4(5.0)$ & & \\
\hline Monthly income & \multicolumn{5}{|c|}{$3.557, \mathrm{df} 6, \mathrm{p}=0.736$} & & \multirow{4}{*}{$* 3.280, p=0.774$} \\
\hline$<$ RM 999 & $186(61.8)$ & $156(83.9)$ & $15(8.1)$ & $8(4.3)$ & $7(3.8)$ & & \\
\hline RM1000 - 4999 & $84(28.0)$ & $65(77.4)$ & $8(9.5)$ & $6(7.1)$ & $5(6.0)$ & & \\
\hline RM5000> & $31(10.2)$ & $28(90.3)$ & $1(3.2)$ & $1(3.2)$ & $1(3.2)$ & & \\
\hline Marital status & \multicolumn{5}{|c|}{$1.273, \mathrm{df} 3, \mathrm{p}=0.736$} & & \multirow[t]{3}{*}{$* 1.327, p=0.743$} \\
\hline Married -Yes & $210(69.8)$ & $174(82.9)$ & $16(7.6)$ & $12(5.7)$ & $8(3.8)$ & & \\
\hline Single/Widow/Divorce & $91(30.2)$ & $75(82.4)$ & $8(8.8)$ & $3(3.3)$ & $5(5.5)$ & & \\
\hline Parity & \multicolumn{5}{|c|}{$2.154, \mathrm{df} 6, \mathrm{p}=0.905$} & & \multirow[t]{4}{*}{$* 2.246, p=0.910$} \\
\hline 0 & $65(21.6)$ & $54(83.1)$ & $5(7.7)$ & $3(4.6)$ & $3(4.6)$ & & \\
\hline $1-3$ children & $131(43.5)$ & $109(83.2)$ & $8(6.1)$ & $8(6.1)$ & $6(4.6)$ & & \\
\hline $4>$ children & $105(34.9)$ & $86(81.9)$ & $11(10.5)$ & $4(3.8)$ & $4(3.8)$ & & \\
\hline Types of childbirth & \multicolumn{5}{|c|}{2.154, df $6, p=0.905$} & & \multirow[t]{11}{*}{$* 11.409, \mathrm{p}=0.055$} \\
\hline Multipara & $65(21.6)$ & $54(83.1)$ & $5(7.7)$ & $3(4.6)$ & $3(4.6)$ & & \\
\hline Vaginal, intact perineum & $141(46.9)$ & $123(87.2)$ & $9(6.4)$ & $6(4.3)$ & $3(2.1)$ & & \\
\hline Vaginal, episiotomy & $36(12.0)$ & $25(69.4)$ & $6(16.7)$ & $3(8.3)$ & $2(5.6)$ & & \\
\hline Forceps \& vacuum & $16(5.3)$ & $11(69.0)$ & $2(12.0)$ & $0(0.0)$ & $3(19.0)$ & & \\
\hline Vaginal tear & $9(3.0)$ & $6(66.7)$ & $1(11.1)$ & $2(22.2)$ & $0(0.0)$ & & \\
\hline Caesarean section & $34(11.2)$ & $30(88.2)$ & $1(2.9)$ & $1(2.9)$ & $2(5.9)$ & & \\
\hline Menopause & \multicolumn{5}{|c|}{ 15.703, df $4, p=0.003$} & & \\
\hline Natural & $128(42.6)$ & $106(82.8$ & $11(8.6)$ & $5(3.9)$ & $6(4.7)$ & & \\
\hline Surgical $/$ medical & $22(7.3)$ & $16(72.7)$ & $0(00)$ & $4(18.2)$ & $2(9.1)$ & & \\
\hline Non-menopause & $151(50.1)$ & $127(84.0$ & $13(8.6)$ & $6(4.0)$ & $5(3.3)$ & & \\
\hline Body Mass Index kg/m² & \multicolumn{5}{|c|}{$3.597, \mathrm{df} 6, \mathrm{p}=0.731$} & & \multirow[t]{4}{*}{$* 3.590, \mathrm{p}=0.739$} \\
\hline $18.5-25$ (optimal) & $127(42.1)$ & $105(82.7)$ & $9(7.1)$ & $6(4.7)$ & $7(5.5)$ & & \\
\hline 25.1 - 30 (overweight) & $126(41.9)$ & $102(81.0)$ & $12(9.5)$ & $6(4.8)$ & $6(4.8)$ & & \\
\hline $30.1>$ (obese) & $48(16.0)$ & $42(87.5)$ & $3(6.3)$ & $3(6.3)$ & $0(0.0)$ & & \\
\hline
\end{tabular}

*When expected frequency (cells were less than 5) or was more than $20 \%$ than Fisher Exact Test was applied

\subsection{Risk Factors Model}

Following risk factors were significantly associated with UI; women with UI were twice as likely (adjusted $\mathrm{OR}=2.080$; $95 \%$ CI $0.900-1.166)$ to have increased BMI $(25.1>)$ than women with UI with optimal BMI $(18$ - 24) or those considered underweight $(\mathrm{BMI}<18)$. Women with UI were thrice as likely (adjusted $\mathrm{OR}=3.633 ; 95 \% \mathrm{CI} 0.997-2.032$ ) to complain of straining too hard during defecation than women with UI who did not. Women with UI were twice as likely (adjusted $\mathrm{OR}=2.002 ; 95 \%$ CI $0.918-3.985$ ) to consume coffee daily than women with UI who did not. Women with UI scoring higher depression score were more likely to report UI (adjusted OR=1.140; 95\% CI 0.999-1.301) than women with UI with lower depression score.

Table 3. Association between risk factors and women with UI.

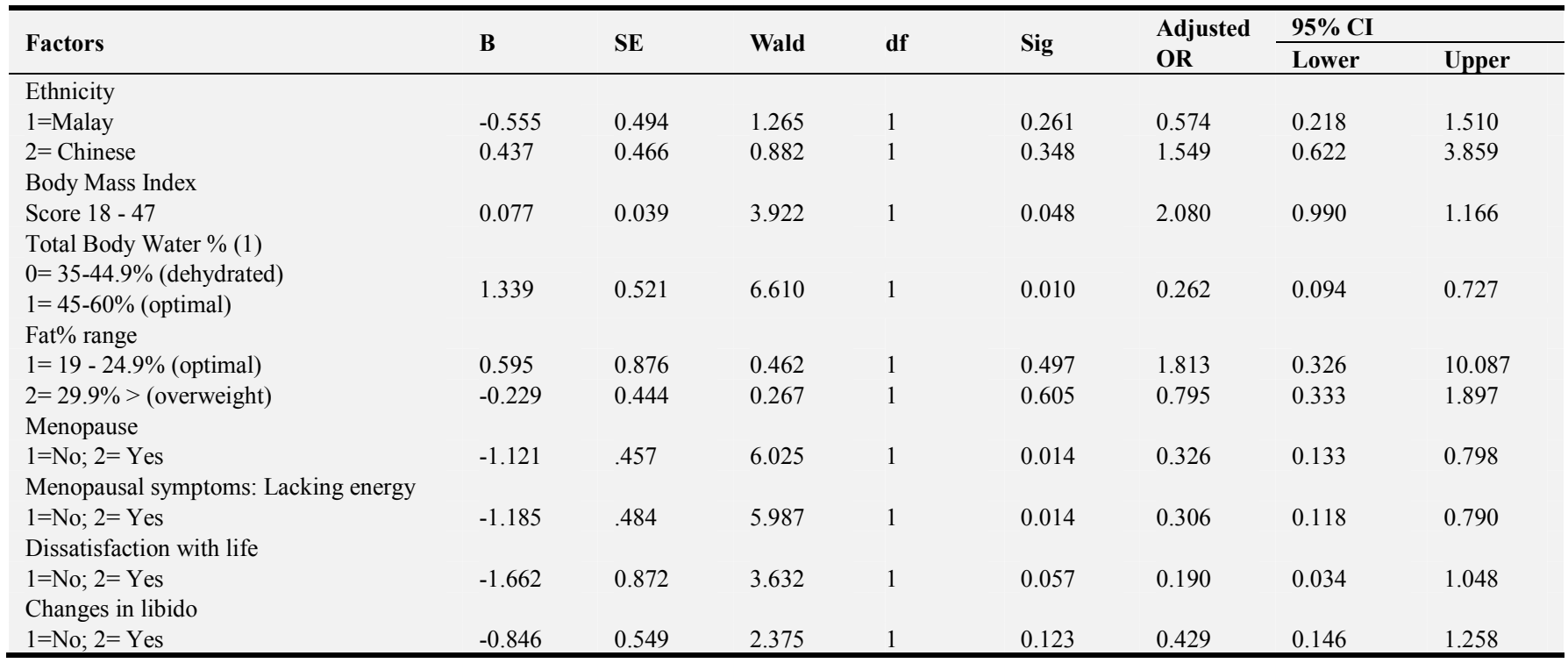




\begin{tabular}{|c|c|c|c|c|c|c|c|c|}
\hline \multirow{2}{*}{ Factors } & \multirow{2}{*}{ B } & \multirow{2}{*}{ SE } & \multirow{2}{*}{ Wald } & \multirow{2}{*}{ df } & \multirow{2}{*}{ Sig } & \multirow{2}{*}{$\begin{array}{l}\text { Adjusted } \\
\text { OR }\end{array}$} & \multicolumn{2}{|c|}{$95 \% \mathrm{CI}$} \\
\hline & & & & & & & Lower & Upper \\
\hline Coffee consumption & & & & & & & & \\
\hline $0=$ none; $1=1-4$ cups $>$ daily & 0.694 & 0.351 & 3.910 & 1 & 0.048 & 2.002 & 0.918 & 3.985 \\
\hline Incomplete emptying after bowel action & & & & & & & & \\
\hline $0=$ No $; 1=$ Yes & 1.289 & 0.723 & 3.177 & 1 & 0.075 & 3.628 & 0.879 & 4.969 \\
\hline $\begin{array}{l}\text { Push on the rectum or vagina to complete } \\
\text { bowel action }\end{array}$ & & & & & & & & \\
\hline $\begin{array}{l}0=\text { No } ; 1=\text { Yes } \\
\text { Strain hard to have a bowel action }\end{array}$ & -1.157 & 0.603 & 3.680 & 1 & 0.055 & 0.315 & 0.096 & 1.025 \\
\hline $\begin{array}{l}0=\text { No; } 1=\text { Yes } \\
\text { Employment }\end{array}$ & 1.290 & 0.611 & 4.460 & 1 & 0.035 & 3.633 & 0.997 & 2.032 \\
\hline $0=$ No; $1=$ Yes & -0.799 & 0.352 & 5.156 & 1 & 0.023 & 0.450 & 0.226 & 0.897 \\
\hline General health score & & & & & & & & \\
\hline $\begin{array}{l}0=0-5 / 15 ; 1=6-15 / 15 \\
\text { Depression score range }\end{array}$ & -0.103 & 0.042 & 6.074 & 1 & 0.014 & 0.902 & 0.831 & 0.979 \\
\hline $0=0-5 / 15 ; 1=6-15 / 15$ & 0.131 & 0.067 & 3.770 & 1 & 0.050 & 1.140 & 0.999 & 1.301 \\
\hline Constant & -1.680 & 1.279 & 1.725 & 1 & 0.189 & 0.18 & & \\
\hline
\end{tabular}

\section{Discussion}

In this study, QUID revealed a prevalence of UI at $17.3 \%$ \pm 0.379 (95\% Confidence Interval 13.2 - 22.0\%; Table 1). However, when the question "Do you ever leak urine, even small drops?", (based on the WHO definition) and answered as either Yes or No), was asked, the prevalence rose to $55.5 \%$ $\pm 5.61(49.89 \%-61.11 \%$; Table 1$)$. Clearly indicating that the construct of the question is very important, and using different definitions for UI, including assessing the severity of urine leak using Likert scale or Yes/No response, impacts the estimation of prevalence of UI in a population. The use of various terminologies and definitions of UI could therefore explain the widely varying prevalence rates of UI reported in the Malaysian studies and in other populations.

An added advantage of using the QUID scoring scale is that it allows for ascertaining the UI subtypes, which is not possible with the WHO definition $[5,7,10]$. Using the QUID score criteria, women in this study who complained of UI $(n=52)$ had complained about the severity of the involuntary urine leak as either 'often', 'almost all the time' or 'all the time'. There was however another $34 \%$ of the women who had reported minimal urine loss/leak (MUL) with a score of 1 to $3 / 15$ and these were not considered to be suffering from UI based on the QUID criteria. The occurrence of urine leak in these women was reported as "rarely" to "once in a while". Although according to QUID, these respondents are not considered to have UI, but going by the WHO definition these respondents would be considered as suffering from UI or "involuntary urine loss". When comparing the prevalence of UI in this study with those reported in other local studies, the prevalence rate was either higher or lower than that reported in other local studies [1, 9, 11-14].

On the types of UI, more participants had complained of SUI than UUI or MUI in this study. A more recent study in the French women documented a prevalence of UI of $26.8 \%$, with almost an equal proportion reporting either SUI (45.2\%) or MUI (42.1\%) and a smaller fraction having UUI (10.9\%) [15]. A slightly different pattern was observed in Turkish women suffering from UI $(23.9 \%)$, where MUI (41.3\%) was more prevalent, followed by SUI (33.1\%) and finally UUI (25.6\%) [16]. The European study showed some similarity with this Malaysian study where most women had complained of SUI but the difference between this Malaysian study and the French study was that more Malaysian women had complained of UUI than MUI, albeit the difference was very small (Table 1). The precise reason for the difference in the pattern of UI types is unclear but might be related to the type of definitions used and perhaps even the type of language used to describe the urinary symptoms in the diagnosis of UI types. Nevertheless, the probability of a racial or ethnic difference existing among women may also need to be addressed in future studies. A number of demographic characteristics and risk factors have been associated with UI and the following demographic characteristics of respondents were considered for their impact on UI. These include age, ethnicity, education, monthly income, marital status, childbirth, parity, menopause status and body mass index (BMI) as shown in Table 2 . The findings of some of these will be elaborated in the ensuing sections.

Age has been positively correlated with prevalence of UI [17]. Using the WHO criteria in this study, more women with UI were between 18 and 64.9 years of age (33.2\%) rather than between 65 and 84.9 years (10.7\%). Another local study had earlier noted that most of the women with UI were aged between 31 to 60 years [12]. Low et al too found that most women with female lower urinary tract symptoms (FLUT) were aged between 20 and 59 years [11]. This finding is however in contrast to a French study that reported a pattern of increased prevalence of UI with increasing age; 50-59 years (30.4\%), 60-69 years $(34.5 \%)$ and $70-79$ years $(34.0 \%)$ [15]. Ahmad et al documenting the prevalence of UI based on respondents' age found that women $<40$ years had slightly lower prevalence $(35.5 \%)$ than those aged $>40$ years $(64.5 \%)$ [14]. The reason/s for the discrepancies is unclear but it nevertheless indicates that UI is a significant problem even in young to middle aged women. Even though more young and middle-aged women reported UI types no significant relationship was observed between UI subtypes and specific age range (Table 2). 
More than half the respondents in this study were premenopausal while the rest were postmenopausal. In this study, almost all menopausal women with UI had menopaused naturally. However, there was a small proportion of postmenopausal women with UI who had undergone the process of menopause abruptly either surgically or medically. Although SUI or UUI was significantly associated with various types of menopause, but in this study, there was zero incident of SUI in those women who had undergone surgical or medical menopause (Table 2). This is inconsistent with previous studies (particularly post hysterectomy) and the reason for this is unclear but may be related to the small sample size $(n=22)$ or duration of follow up. Some investigators had postulated menopausal status, especially in those in the older age group, as a risk factor for UI [18-20]. However, unlike the Australian women who suffer from increased rate for UI while aging, UI was more prevalent during the premenopausal and early menopause transition in women in this study [21]. This finding is also in support of the earlier findings by Ahmed et al who reported similar percentage of respondents with UI in both pre and postmenopausal women [14]. The reason as to why the prevalence was not higher in postmenopausal women compared to the premenopausal women is unclear. Interestingly, postmenopausal women with UI who complained of "lack of energy" or tiredness were less likely to report UI than postmenopausal women with UI who were energized or did not complain of tiredness $(p=0.014$, Table 3 ). The significance of "lack of energy" may be related to a lack of vigorous physical activities among women, which is known to be associated with UI particularly SUI. It also suggests that the complaint of UI might be under reported in postmenopausal women. Clearly, much still needs to be done to establish the exact impact of menopause on UI.

There was a positive correlation noted between BMI and UI $(p=0.048$, Table 3$)$ in this study, which is consistent with multiple other studies. Positive significant correlation between BMI and UI has also been reported before whereby Huaskar's systematic review, had suggested a stronger association between weight and SUI, than either with UUI or overactive bladder syndrome [22]. It has been widely speculated that obesity contributes to SUI through increased intra-abdominal pressure from central adiposity, which in turn increases bladder pressure and urethral mobility, thus exacerbating UI [22]. The same mechanisms are also thought to exacerbate detrusor instability and overactive bladder [22]. In addition, Malaysian overweight and obese women with UI were more likely to report UI than those women with UI who were underweight (Table 3). Whilst the reason for this is not apparent, it might be related to UI being more troublesome in overweight and obese women than in normal weight women.

The study's findings of a positive correlation between pelvic floor distress symptoms and UI are entirely consistent with other studies too. Female pelvic floor distress (PFD) symptoms are now increasingly recognized as another insidious health problem associated with female UI. Three pelvic floor distress symptoms; straining too hard during defecation, feeling of incomplete emptying of bowel after defecation and pushing on rectum or vagina to complete defecation, were associated with UI in Malaysian women. It was found that respondents who strained too hard to have bowel action were thrice more likely to report UI than women with UI who were able to defecate with ease ( $p=0.035$ Table 3 ). This finding is similar to that reported by Sengupta and Hillard who found that the most common health issues among the early postmenopausal period were utero-vaginal pelvic organ prolapse, UI, UTI and urogenital atrophy [23]. Excessive straining could cause increased perineal decent, which may stretch and result in damage to the pudendal nerve, including, making the anorectal angle more than 90 degrees [24]. Women with PFD and UI can no longer be placed as if belonging to a very small minority. Instead, PFD complaints do affect a significant fraction of women whether with or without UI, as evident from this study.

More than half the women within the cohort consumed coffee; instant (caffeine 30 - $90 \mathrm{mg}$ ) or local coffee (caffeine 65-125 mg). In this study, most women drank a cup (150-200 $\mathrm{ml}$ ) per day while less than a quarter of the women drank between 2 and 4 cups of coffee per day. None of the previous studies on Malaysian women had reported any significant association between coffee consumption and UI or with its severity. A meta-analysis of seven studies too found no evidence associating coffee/caffeine consumption with risk of UI [25]. A Korean study on postmenopausal women however reported an increase in the prevalence of UI with higher caffeine consumption [26]. A recent study also found that high caffeine intake $(>450 \mathrm{mg} /$ day) was associated with frequent UI and UUI [27]. Similar findings were also made by Gleason et al who reported that caffeine intake was associated with UI as well as with the degree of severity of UI [28]. The reason/s for this discrepancy in the association between UI and coffee consumption is unclear. Caffeine consumption has a well-known diuretic effect. It prevents the vasoconstriction of the renal afferent arterioles and thereby increases glomerular filtration rate and with it perhaps urine output. It also inhibits proximal tubular sodium reabsorption. This might therefore increase urine formation and frequency of micturition. The impact of coffee consumption on UI therefore revealed that women with UI who drank coffee daily were twice more likely to report UI than women with UI who did not consume coffee (Table 3). This study was unable to elucidate association between daily coffee consumption and different types of UI particularly UUI.

Most Malaysian women with UI scored between 1 and $10 / 15$ in the general health score domain of psychological general wellbeing index questionnaire (PGWBI). In the UI subtypes, general health score was associated with women suffering from SUI and UUI (Table 3). Unlike the Australian women, most Malaysian women did not consider mild to moderate degree of UI as bothersome nor did it affect their general wellbeing. Malaysian women with UI and with a general health score of 6 to $10 / 15$ had a better sense of well- 
being and were less likely to report UI than women with UI scoring $<5$ or $>11 / 15$ in the general health domain (Table 3 ) Similar to the Australian study, whereby woman with UI had a lower total PGWBI score than women with no UI, Malaysian women with UI too were more likely to score a higher depression score than women with UI with low depression score (Table 3) [29]. However, there was a fraction of Malaysian women without UI who had low scores in all PGWBI domains, which would invariably indicate that they had reduced quality of life irrespective of suffering from UI or not. A review of population studies on UI by Avery and Stocks had cited depression and psychological factors associated with UI [30]. Some studies had observed significantly higher rate of depression amongst those with UI [30] Conflicting findings between this study and those conducted abroad indicate a difference in how UI symptoms is viewed or tolerated.

Equal proportion of employed and unemployed women complained of UI. In this study, more women with UI were from the lower educational and income bracket. Interestingly, Malaysian women with UI who were in employment were however less likely to report UI compared to unemployed women with UI (Table 3). There was no significant relationship between education and monthly income and UI, indicating that neither education nor income level impacted on the prevalence of UI among Malaysian women.

Although ethnicity was not an inclusive criterion, but based upon the sampling technique, there were slightly more women of Chinese than of Malay or Indian origin in this study. SUI was more prevalent amongst women of Malay and Chinese origins than women of Indian origin. UUI was more prevalent in women of Indian and Chinese origins than women of Malay origin (Table 2). In addition, more Chinese and Indian respondents than Malay respondents reported MUI. The exact significance of this is unclear and little has been documented on this in the Malaysian population before. The various studies that have been done on Malaysian women had consisted of study samples where the ethnicity of the study sample had varied from $100 \%$ Malay to sample populations from the various ethnic communities. In none of these studies a link between ethnicity and type of UI was reported. For example, Low et al's, study consisted of women of Chinese, Malay, Indian and other origins [11]. Samiah et al's study in Terengganu on the other hand had a sample population of only Malay women [13]. Similarly, Zalina et al's study sample comprised mainly of Malay students [1]. To make a comparison in the prevalence of UI among the various ethnic groups with the recent local studies is therefore not possible as UI along with ethnicity was not reported in any of the other studies. However, irrespective of ethnic groups it was clear that the prevalence of UI was definitely higher among Malaysian women in this study than reported in previous studies. Table 2 clearly illustrated that among women who had UI, SUI was more common among the Malay and Chinese women, UUI was present more among Chinese and Indian women and MUI was frequently reported by Chinese women.
Child birth has been identified as a risk factor in UI [1] but in this study, however no significant correlation was observed between childbirth and UI or UI subtypes (Table 2). Although the complaint of UI subtypes in women who had experienced childbirth, and those who had undergone vaginal deliveries with episiotomy was higher than those who never experienced pregnancy, the differences were not statistically significant (Table 2). Most women in this study had parity of between none to more than 4 children, but no significant association was evident between UI and parity. In contrast, a number of local studies had associated parity of two children and more with [11]. Ahmad et al reported that women who suffered from overactive bladder (OAB) had a parity of two to more than five children [14]. The reason for this is not apparent. In addition, marital status has been suggested as one of the risk factors for UI [1] but no significant correlation was evident between UI and marital status in this study (Table 2).

\section{Conclusion}

In comparison to the prevalence of UI globally (15\% $55 \%)$ and UI estimates among community dwelling women worldwide $(10 \%-40 \%)$, the prevalence in this study ranked at the lower end $(17.3 \%)$ of both the ranges. The most common UI types was SUI followed by UUI and MUI. The risk factor model demonstrated a clear association between UI and increased BMI, daily coffee consumption, straining too hard during defecation, and higher depressive score. This study also identified important consideration regarding UI and its impact on the psychological health of the Malaysian women. Clearly, more studies are needed to fully ascertain the prevalence of UI types and the use of QUID might help provide a better and more accurate prevalence in the community. The low well-being amongst women with UI stresses upon the need to determine whether sufficient guidelines for assessment, and counseling are present within the community health care centres and hospital settings to ensure early detection of women with both urinary problems and reduced mental wellbeing.

\section{Abbreviations}

UI: urinary incontinence, SUI: stress urinary incontinence, UUI: urge urinary incontinence, MUI: mixed urinary incontinence, MUL: minimal urine leak, QUID: questionnaire urinary incontinence diagnosis, MMWHQ: Malay Monash women health questionnaire, BMI: body mass index.

\section{Availability of Data and Material}

The datasets supporting the conclusion of this article are available via the Research Management Office, Jeffrey Cheah School of Medicine and Health Sciences, Monash University Malaysia. 


\section{Limitation of Study}

The population sample size $(\mathrm{n}=301)$ was appropriate in calculating the overall prevalence of UI but was insufficient to analysis the prevalence of difference types of UI.

\section{Ethical Considerations}

Ethical approval was obtained from the Medical Research and Ethics Committee, Ministry of Health Malaysia (Project no: NMRR-11-149-8830). Monash University Human Research Ethics Committee Certificate of Approval was obtained from August 2011-2016 (Project no. CF10/17252010000963). During recruitment written informed consent was obtained from all participants who met the inclusion criteria.

\section{Finance and Resource Use}

Monash University Seed Grant was obtained from the cardio-metabolic research cluster in 2008 and 2009 respectively and the Ministry of Science, Technology and Innovation (MOSTI) e-Science Fund Project no: 06-02-10SF0103 funded the main project.

\section{Authors' Contributions}

Hardip Kaur Dhillon is responsible for the preparation of the Malay version of the questionnaire, design and implementation of the project, obtaining ethical approval, securing project funds, data analysis and writing of manuscript. Quek Kia Fatt, Gurpreet Kaur and Rusli Nordin contributed towards preparation of the Malay version questionnaire, the statistical tests and data analysis. Harbindar Jeet Singh contributed toward the research design, data interpretation including editing the first draft of manuscript. All authors approved the final manuscript and consented to its publication.

\section{Conflict of Interest}

The authors declare that they have no competing interests.

\section{Acknowledgements}

The authors acknowledge that both the English language Questionnaire urinary incontinence (QUID) and Monash Women Health Questionnaire (MWHQ) were obtained from Robin J Bell and Susan R Davis, Women's Health Program and Department of Epidemiology and Preventive Medicine, Monash University Victoria, Australia.

\section{Appendix}

\section{Appendix A. English Language}

This is the 'Questionnaire for Urinary Incontinence Diagnosis' (QUID). This questionnaire assists in finding more about the type of urinary incontinence women experience. Please put a cross in ONE box for each question囚. In the last one month do you?

Table A1. Questionnaire for Urinary Incontinence Diagnosis (QUID).

\begin{tabular}{|c|c|c|c|c|c|c|}
\hline Questions & $\begin{array}{l}\text { None of } \\
\text { the time }\end{array}$ & Rarely & $\begin{array}{l}\text { Once in a } \\
\text { while }\end{array}$ & Often & $\begin{array}{l}\text { Most of } \\
\text { the time }\end{array}$ & $\begin{array}{l}\text { All of the } \\
\text { time }\end{array}$ \\
\hline \multicolumn{7}{|c|}{ Do you leak urine (even small drops), wet yourself, or wet your pads or undergarments...? } \\
\hline 1. When you cough or sneeze? & $\square$ & $\square$ & $\square$ & $\square$ & $\square$ & $\square$ \\
\hline 2. When you bend down or lift something up? & $\square$ & $\square$ & $\square$ & $\square$ & $\square$ & $\square$ \\
\hline 3. When you walk quickly, jog, or exercise? & $\square$ & $\square$ & $\square$ & $\square$ & $\square$ & $\square$ \\
\hline 4. While you are undressing to use the toilet? & $\square$ & $\square$ & $\square$ & $\square$ & $\square$ & $\square$ \\
\hline $\begin{array}{l}\text { 5. Do you get such a strong and uncomfortable need to urinate } \\
\text { that you leak urine (even small drops) or wet yourself before } \\
\text { reaching the toilet? }\end{array}$ & $\square$ & $\square$ & $\square$ & $\square$ & $\square$ & $\square$ \\
\hline $\begin{array}{l}\text { 6. Do you have to rush to the bathroom because you get a } \\
\text { sudden, strong need to urinate? }\end{array}$ & $\square$ & $\square$ & $\square$ & $\square$ & $\square$ & $\square$ \\
\hline
\end{tabular}

\section{Appendix B. Malay Version}

Soal-selidik mengenai 'Urinary Incontinence Diagnosis' (QUID) ini boleh membantu mencari lebih banyak maklumat mengenai jenis-jenis penyakit hilang kawalan membuang air kecil di kalangan wanita. Sila tandakan $\bigotimes$ bagi setiap soalan. Dalam tempoh satu bulan lepas adakah..........?

Table A2. Hlang Kawalan Buang Air Kecil: Pengesahan Penyakit.

\begin{tabular}{|c|c|c|c|c|c|c|}
\hline Soalan & $\begin{array}{l}\text { Tidak pernah } \\
\text { terjadi }\end{array}$ & $\begin{array}{l}\text { Jarang } \\
\text { terjadi }\end{array}$ & $\begin{array}{l}\text { Sekali- } \\
\text { sekala }\end{array}$ & Kerap & $\begin{array}{l}\text { Kebanya- } \\
\text { kan masa }\end{array}$ & $\begin{array}{l}\text { Sepanjang } \\
\text { masa }\end{array}$ \\
\hline \multirow{3}{*}{$\begin{array}{l}\text { Adakah kencing anda terkeluar (walaupun titisan kecil), } \\
\text { membasahkan anda, atau membasahi seluar dalam atau tuala } \\
\text { wanita anda ketika keadaan-keadaan di bawah; } \\
\text { 1. Ketika anda terbatuk atau terbersin? } \\
\text { 2. Ketika anda membengkokkan badan atau ketika anda } \\
\text { mengangkat sesuatu barang? }\end{array}$} & $\square$ & $\square$ & $\square$ & $\square$ & $\square$ & $\square$ \\
\hline & $\square$ & $\square$ & $\square$ & $\square$ & $\square$ & $\square$ \\
\hline & $\square$ & $\square$ & $\square$ & $\square$ & $\square$ & $\square$ \\
\hline
\end{tabular}




\begin{tabular}{|c|c|c|c|c|c|c|}
\hline Soalan & $\begin{array}{l}\text { Tidak pernah } \\
\text { terjadi }\end{array}$ & $\begin{array}{l}\text { Jarang } \\
\text { terjadi }\end{array}$ & $\begin{array}{l}\text { Sekali- } \\
\text { sekala }\end{array}$ & Kerap & $\begin{array}{l}\text { Kebanya- } \\
\text { kan masa }\end{array}$ & $\begin{array}{l}\text { Sepanjang } \\
\text { masa }\end{array}$ \\
\hline 3. Ketika anda berjalan dengan cepat, joging atau bersenam? & $\square$ & $\square$ & $\square$ & $\square$ & $\square$ & $\square$ \\
\hline 4. Ketika anda membuka pakaian untuk ke tandas? & $\square$ & $\square$ & $\square$ & $\square$ & $\square$ & $\square$ \\
\hline $\begin{array}{l}\text { 5. Pernahkah anda berasa begitu terdesak sehingga anda } \\
\text { terkencing (walaupun titisan kecil) sebelum sampai ke tandas? }\end{array}$ & $\square$ & $\square$ & $\square$ & $\square$ & $\square$ & $\square$ \\
\hline $\begin{array}{l}\text { 6. Pernahkah anda tergesa-gesa pergi ke tandas disebabkan rasa } \\
\text { ingin terkencing yang datang secara tiba-tiba? }\end{array}$ & $\square$ & $\square$ & $\square$ & $\square$ & $\square$ & $\square$ \\
\hline
\end{tabular}

\section{References}

[1] Dhillon HK, MZain AZ, Quek KF, Singh HJ, Kaur G, Nordin RB. Prevalence and Risk Factors of Urinary Incontinence and its Impact on the Quality of Life and Treatment Seeking Behavior among Malaysian Women: A Review. J Women's Health Care. 2016; 5: 337. doi: 10.4172/2167-0420.10003.

[2] Yip SK, Cardozo L. Psychological morbidity and female urinary incontinence. Best Pract Res Clin Obstet Gynaecol. 2007 Apr; 21 (2): 321-9. Available from: DOI: http://dx.doi.org/10.1016/j.bpobgyn.2006.12.002

[3] Bradley CS, Rovner ES, Morgan MA, Berlin M, Novi J, Shea J, Arya LA. A new questionnaire for urinary incontinence diagnosis in women. Development and testing. Am J Obstet Gynecol 2005 Jan; 192 (1): 66-73. DOI: http://dx.doi.org/10.1016/j.ajog.2004.07.037. Available from: http://www.ajog.org/article/S0002-9378(04)00797-5/abstract

[4] Dhillon HK, MZain AZ, Singh HJ, Kaur G, Nordin RB, Quek KF. A Study Protocol Using the Malay QUID in Selangor, Malaysia J Women's Health Care 2016, 5: 6. DOI: 10.4172/2167-0420.1000338.

[5] Dhillon HK, Md. Zain Anuar Zaini, Quek KF, Singh HJ, Kaur G, Rusli bin Nordin. Exploratory and confirmatory factor analyses for testing validity and reliability of the Malay Language Questionnaire for Urinary Incontinence Diagnosis (QUID) Open Journal of Prevention Medicine 2014; 4, 844 851 Published Online November 2014 in SciRes. http://www.scirp.org/journal/ojpm

[6] Dhillon HK, Rusli bin Nordin, Ghazali Othman, Nurulhuda Zainol, NorhayatiAbdul Malek, Shameema Banu Ahmed Ibrahim. Malay version Monash Malaysian Women Health Questionnaire version-1. Jeffrey Cheah School of Medicine and Health Sciences. Monash University Malaysia. 2011. http://dx.doi.org/10.4236/ojpm.2014.411095.

[7] Myers L. Female mixed urinary incontinence: A clinical review JAMA 2014 May; 311 (19): 2007-2014. doi. 10.1001/jama.2014.4299.

[8] Hunskaar S, Burgio K, Diokno A, Herzog, R, Hjalmas, K, \& Lapitan, M. Epidemiology and natural history of urinary incontinence in women. Urol. 2003 Oct; 62 (4 Suppl 1): 16-23.

[9] Mohamad Amin Pourhoseingholi, Mohsen Vahedi, Mitra Rahimzadeh. Sample size calculation in medical studies. Gastroenterol Hepatol Bed Bench 2013; 6 (1): 14-17.

[10] WHO 2017 ICD-10-CM Diagnosis Code N39.3 Stress incontinence (female). http://www.icd10data.com/ICD10CM/Codes/N00-N99/N30N39/N39-/N39.3

[11] Low BY, Liong ML, Kah HY, Chong WL, Chee C, Wing SL et al. Study of prevalence, treatment-seeking behaviour, and risk factors of women with lower urinary tract symptoms in Northern Malaysia. Urol. 2006 Oct; 68 (4): 751-758. Available from: doi: http://dx.doi.org/10.1016/j.urology.2006.05.021

[12] Dhillon HK, Singh HJ, Shuib R, Abdul Manaf H, Nik Mohd Zaki Nik Mahmood. Prevalence of menopausal symptoms among women in Kelantan. Malaysia. Maturitas 2006 Jun; 54 (3): 213-221. DOI: 10.1016/j.maturitas.2005.11.001. Available from: https://www.ncbi.nlm.nih.gov/pubmed/16326052

[13] Samiah Yasmin AK, Karim Al-Jashamy, Rohaini Mohamed, Pathak R, Vinothini A, Aye Aye Mon. Prevalence of urinary incontinence and associated risk factors among married women. Indian Journal of Applied Science 2013; 3 (7): 491495.

[14] Ahmad SM, Aznal SS, and Tham SW. Prevalence of an overactive bladder syndrome (OABS) among women with gynaecological problems and its risks in a tertiary hospital, Negeri Sembilan, Malaysia: Implications for a primary health care provider. Malays Fam Physician 2015; 10 (2): 2-8. PMC4826576.

[15] Lasserre A, Pelat C, Gueroult V, Hanslik T, Chartier-Kastler E, et. al. Urinary incontinence in French women.: prevalence, risk factors and impact on quality of life. Eur. Uro. 2009; 56: 177-183.

[16] Kocak I, Okyay P, Dundar M, Erol H, Beser E. Female urinary incontinence in the West of Turkey: Prevalence, risk factors and impact on quality of life. Eur. Uro. 2005; 48: 634641.

[17] Gibson W, Wagg A. New horizons: urinary incontinence in older people. Age and Ageing 2014; 43: 157-163. doi: 10.1093/ageing/aft214.

[18] Townsend M, Danforth K, Rosner B, Burhan G, Resnick N, Grodstein F. Body mass index, weight gain and incident urinary incontinence in middle-aged women. Obstet \& Gynecol 2007 Aug; 110 (2 Pt1): 346-353. DOI: 10.1097/01.AOG.0000270121.15510.57. Available from: https://www.ncbi.nlm.nih.gov/pubmed/17666610

[19] Milsom I, Ekelund P, Molander U, Arvidsson L, Areskong B. The influence of age, parity, oral contraception, hysterectomy and menopause on the prevalence of urinary incontinence in women. J Urol. 1993 Jun; 149 (6): 1459-1462. Available from: https://www.ncbi.nlm.nih.gov/pubmed/8501788

[20] Mishra GD, Cardoza L, Kuh D. Menopausal transition and the risk of urinary incontinence: results from a British cohort. BJUI 2010; 106: 1170-1175. doi: 10.1111/j.1464-410x.2010. 09321.x.

[21] Botlero R, Davies S, Urquhart D, Shortreed S, Bell R. Agespecific prevalence, different types of urinary incontinence, in community-dwelling Australian women assessed with a validated questionnaire. Menopause. 2010 Mar; 17 (2): 332337. DOI: 10.12968/bjon.2010.19.12.48651. 
[22] Hunskaar S A systematic review of overweight and obesity as risk factors and targets for clinical intervention for urinary incontinence in women. Neurourol and Urodyn 2008; 27: 749757. Doi: 10.1002/nau.20635 Available from: http://www.gnmhealthcare.com/pdf/102008/29/1666564_Asys tematicreviewofoverwe.pdf

[23] Sengupta N, Hillard T. Urogynecological risk assessment in postmenopausal women. Expert Rev. Obstet. Gynecol. 2013; 8 (6), 625-637. DOI://10.1586/17474108.2013.851847.

[24] Bharucha AE, Dunivan G, Goode P, Lukacz ES, Markland $\mathrm{AD}$, Mathews $\mathrm{C}$, et al. Epidemiology, pathophysiology, and classification of fecal incontinence: State of the science summary for the national institute of Diabetes and Digestive and Kidney Diseases (NIDDK) workshop. Am J Gastroenterol 2015; 110: 127-136. doi: 10.1038/ajg.2014.396.

[25] Sun S, Liu D, Jiao Z. Coffee and caffeine intake and risk of urinary incontinence: a meta-analysis of observational studies. BMC Urol. 2016; 16: 61. Doi 10.1186/s12894-016-0178-y.

[26] Baek JM, Song JY, Lee SJ, Park EK, Jeung IC, Kim CJ, Lee YS. Caffeine Intake Is Associated with Urinary Incontinence in Korean Postmenopausal Women: Results from the Korean National Health and Nutrition Examination Survey. PLoS ONE 2016; $11 \quad$ (2): e0149311. https://doi.org/10.1371/journal.pone.0149311. m. Int J
Gynecol Obstet 2003 Sep; 82 (3): 327-338. doi: 10.1016/S0020-7292Ž03.00220-0.

[27] Juru YH, Townsend MK, Curhan GC, Resnick NM, Grodstein F. Caffeine intake and risk of stress, urgency, and mixed urinary incontinence. J Urol. 2011 May; 185 (5): 1775-1780. doi: 10.1016/j.juro.2011.01.003.

[28] Gleason JL, Richter HE, Redden DT, Goode PS, Burgio KL, Markland AD. Caffeine and urinary incontinence in US women. Int Urogynecol J. 2013 Feb; 24 (2): 295-302. doi: 10.1007/s00192-012-1829-5.

[29] Botlero, R. Robin, B., Urquhart, D. M. \& Davis, S. R., Urinary incontinence is associated with lower psychological general well-being in community-dwelling women. Menopause. 2010 Mar; 17 (2): 332-337. DOI: 10.12968/bjon.2010.19.12.48651.

[30] Avery J, Stocks N. Urinary incontinence, depression and psychosocial factors: a review of population studies. Euro Med J. 2016 Jan; 1 (1): 58-67. Available from: http://emjreviews.com/wp-content/uploads/UrinaryIncontinence-Depression-and-Psychosocial-Factors-AReview-of-Population-Studies.pdf 